\title{
David Oliver: How can we plan for old age if we won't discuss it honestly?
}

\section{David Oliver consultant in geriatrics and acute general medicine}

Berkshire

Media depictions of ageing have become polarised. On the one hand we have skydiving grannies, marathon running granddads, and national treasures such as Judi Dench and David Attenborough. And then we have "The Elderly"-hapless victims of neglect, passive recipients of care, burdens on public services, and part of a "grey tsunami."

Over the past few months, an avalanche of articles and books has told us how to stave off ageing and remain as fit as we can for as long as we can. To paraphrase: "70 is the new 45 , you're as young as you feel, and I'm certainly not old, let alone senile or doddery."

In May a 67 year old Times columnist, Elaine Kingett, wrote about retaining her sexual life and desirability, dating and outpacing younger men. ${ }^{1}$ She asked why she should have to wear fleeces, forget about sex, and "look out on a desert full of internet dating geriatrics" whose idea of fun ventured no farther than a potter around a garden centre or a nap.

Of course, there's no reason not to enjoy an active sex life or dating as we age, if we choose to. And, with major inequalities in disability-free life expectancy and much potentially preventable ill health in older age, ${ }^{2}$ our interest in remaining fit makes sense. ${ }^{3}$ Who wants to be in poor health as they age, if they can avoid it? As Bette Davis said, "Old age ain't no place for sissies!"

An avalanche of articles and books has told us how to stave off ageing and remain as fit as we can for as long as we can

Paradoxically, all of this can reinforce ageist attitudes, so that older people cease to have human worth, moral value, or visibility if they don't look and act younger in terms of fashion, fitness, sexuality, work, and technology. ${ }^{4}$ They can feel like a burden on society. ${ }^{5}$ Older people generally prefer to discuss their health in terms of maximising what they can still do-their assets, not their deficits. ${ }^{3}$ And planning for future end of life care is often unwelcome unless they know that they have a life limiting illness. ${ }^{6}$
Yet, however much we invest in healthy ageing, we will accumulate long term conditions with age, including sensory, mobility, or cognitive impairment. ${ }^{27}$ Around a quarter of England's over $65 \mathrm{~s}$ live with moderate or severe frailty, increasing the likelihood of health and care service use and reducing life expectancy. ${ }^{8}$

The only way to avoid getting older is to stop living. A desperate distancing from the uncomfortable fact of our own ageing and mortality feeds a failure to plan for future housing and care, potential loss of mental or physical capacity, or difficult decisions towards the end of life. Behaving like ostriches will make us rabbits in the headlights when reality strikes.

\section{Competing interests: See www.bmj.com/about-bmj/freelance-} contributors/david-oliver.

Provenance and peer review: Commissioned; not externally peer reviewed.

Follow David on Twitter: @mancunianmedic

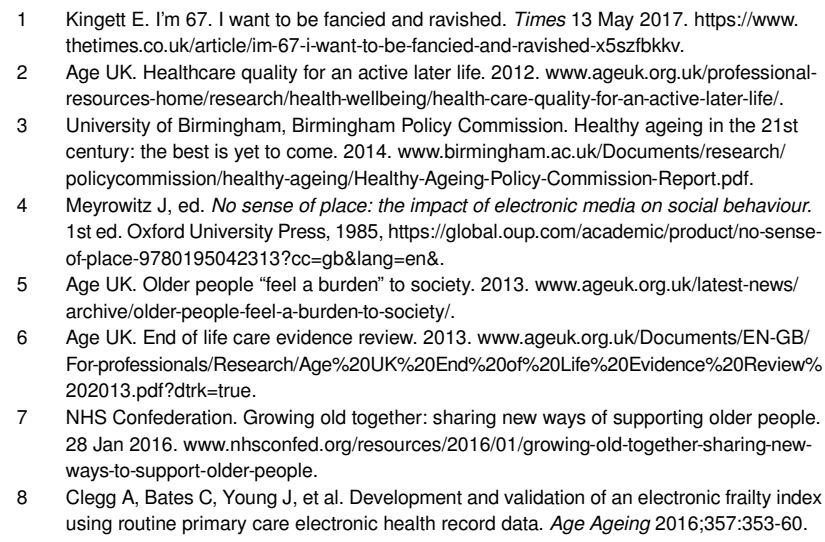
doi:10.1093/ageing/afw039 pmid:26944937.

Published by the BMJ Publishing Group Limited. For permission to use (where not already granted under a licence) please go to http://group.bmj.com/group/rights-licensing/ permissions 